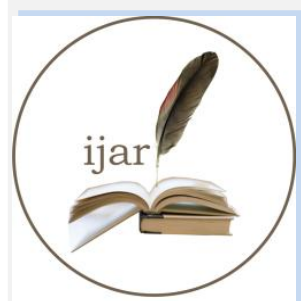

ISSN NO. 2320-5407
Journal Homepage: - www.journalijar.com INTERNATIONAL JOURNAL OF ADVANCED RESEARCH (IJAR)

Article DOI: $10.21474 / \mathrm{IJAR} 01 / 1515$

DOI URL: http://dx.doi.org/10.21474/IJAR01/1515

RESEARCH ARTICLE

\title{
PON1 GENE POLYMORPHISM AND SERUM PARAOXONASE LEVELS IN WOMEN OCCUPATIONALLY EXPOSED TO ORGANOPHOSPHATE PESTICIDES IN SOUTH INDIA.
}

Priyanka Pallapolu ${ }^{1}$, Chaitanya Kumar Bhukya ${ }^{1}$, Sailaja Maddhuri ${ }^{1}$, Sunitha Tella ${ }^{1}$, Jyothy Akka ${ }^{1}$, Pardhanandana Reddy Penagaluru ${ }^{2}$, Pratibha Nallari ${ }^{1}$ and Hema Prasad Mundluru ${ }^{1 *}$.

1. Institute of Genetics and Hospital for Genetic Diseases, Osmania University, Begumpet, Hyderabad-500016, India.

2. Bhagwan Mahavir Medical Research Centre, A.C. Guards, Hyderabad-500004, India.

\section{Manuscript Info}

\section{Manuscript History}

Received: 12 July 2016

Final Accepted: 19 August 2016

Published: September 2016

Key words:-

Women workers; Paraoxonase; Organophosphates; Detoxification;

Disease susceptibility.

\section{Abstract}

Introduction and Objective:- Paraoxonase (PON1) enzyme detoxifies organophosphates (OPs) by cleavage of active oxons. PON1L55M and PON1Q192R gene polymorphisms affect the enzyme activity and increase susceptibility to OP toxicity. Hence, the present study is aimed to assess the association of serum PON1 levels and PON1 polymorphisms (PON1L55M and PON1Q192R) in women occupationally exposed to organophosphate pesticides.

Materials and Methods:- Demographic and occupational data were collected by means of a standard questionnaire from 205 exposed and 212 control subjects belonging to same age, sex and socioeconomic status. Serum paraoxonase levels were analyzed by ELISA kit method. Paraoxonase-1 L55M and Q192R genotype was detected by PCR and RFLP method.

Results:- Serum paraoxonase levels were significantly decreased in the exposed group $(7.61 \mathrm{ng} / \mathrm{mL})$ when compared to control group $(13.09 \mathrm{ng} / \mathrm{mL})$. In PON1 L55M genotype the frequency of the mutant allele 'A' was found to be $27 \%$ in exposed and $19 \%$ in controls (OR $=1.64,95 \%$ CI: $1.18-2.27 ; p=0.003$ ) whereas in PON1 Q192R genotype did not show any statistical significance. Linkage disequilibrium between the variants of PON1 was found to be strong $\left(\mathrm{D}^{\prime}>0.7\right)$.

Conclusion:- A significant association of serum paraoxonase levels with PON-1 L55M and Q192R gene polymorphisms was observed in women occupationally exposed to OP pesticides. Thus, the study emphasizes the importance of serum PON1 enzyme levels and its association with PON1 gene polymorphisms and serum PON1 enzyme levels can be potential biomarker for OP-susceptible individuals, especially in occupationally exposed populations for risk assessment. 


\section{Introduction:-}

Pesticides are hazardous chemicals used extensively in agriculture for the protection of crops against pests (Aristidis et al, 2011). Organophosphates (OP) pesticides are widely used neurotoxic insecticides which include compounds such as chlorpyrifos, diazinon, and malathion in south India. Apart from the benefits of OP pesticides on agricultural productivity, OP pesticides causes impaired ability to hydrolyze acetylcholine a common neurotransmitter in both the peripheral and central nervous systems by phosphorylation and subsequent inhibition of the enzyme acetylcholinesterase in humans. Excess acetylcholine can cause severe toxicity and lead to several neuromuscular disorders and disease susceptibility (Mackenzie Ross et al., 2010). A wide range of health problems are also associated with acute or long-term OP exposure, ranging from respiratory problems (Baldi et al., 2014) to neuropsychiatric disorders (Mackenzie Ross et al., 2010) and teratogenic or carcinogenic effects (Vakonaki et al., 2013).

In humans OP pesticide exposure and disease susceptibility are more complex than initially thought as several phase I and phase II enzymes are involved in the metabolism and detoxification (Tsatsakis et al., 2009). Human PON-1 is a calcium-dependent esterase which is synthesized in the liver and transported to the serum along with HDLs. PON1 enzyme has several functions including detoxification of various OP compounds and also prevents the oxidation of low-density lipoproteins, which impairs the development of atherosclerotic plaques. PON-1 mainly acts on the metabolites of OP compounds formed after oxidative desulfurization of the OP parent compound by the cytochrome P450 system in liver. PON-1 enzyme levels observed are high in liver and serum (Costa et al, 2006). There are two common polymorphisms of the PON1 in the coding sequence, a $\operatorname{Gn}(\mathrm{Q}) / \operatorname{Arg}(\mathrm{R})$ substitution at position 192 and a $\mathrm{Leu}(\mathrm{L}) / \mathrm{Met}(\mathrm{M})$ substitution at position 55. These polymorphisms alter the OP detoxification ability in human s by altering serum enzyme levels (Costa et al, 2005a).

PON1 enzyme was considered to be one of the most important biomarker of susceptibility to long term exposure to OP pesticides. Alterations in this enzyme activity and serum concentrations may contribute to inter individual variations in disease susceptibility.(Hernandez et al., 2003; Costa et al., 2005b; Sirivarasai et al., 2007; Zhou et al, 2007 \& Perez-Herrera et al., 2008). From previous animal studies it is evident that low or no serum PON-1 activity animals were found to be more sensitive to OP toxicity than high activity animals (Costa et al, 1999). Apart from polymorphisms PON-1 levels also play a major role in modulating the toxicity of some OPs. But the relationship between an individual's PON-1 genotype and its interaction with OPs still remains unclear in human population and requires further research in occupationally OP exposed. Hence, the present study is aimed to determine the role of serum paraoxonase levels and PON 1 gene polymorphisms in women agricultural workers occupationally exposed to OP pesticides from south India.

\section{Study group:-}

Among the 417 individuals recruited for the study 205 women were agricultural workers occupationally exposed to OP pesticides from rural zones of the Nalgonda and Guntur districts of South India and 212 women were included for control group. A written informed consent was obtained from exposed and control groups. The study was approved by the ethics committee of Institute of Genetics and Hospital for Genetic Diseases, Hyderabad. Information on age, habits, working hours per day, years of exposure, nature of work, medical history and marital life was collected using a standard questionnaire from both the groups. Blood samples were collected by venopuncture in vacutainer tubes with EDTA as anticoagulant and plain tubes for serum. Approximately 10-12 samples at the end of their work shift were collected from exposed and control subjects each time from rural zones of the Nalgonda and Guntur districts of South India. All the samples were safely transported on ice to the laboratory and processed within 12 hours. Blood samples were centrifuged to separate serum and stored at $-80^{\circ} \mathrm{C}$ until analysis.

\section{DNA isolation and genotyping:-}

The genomic DNA was extracted from venous blood collected in EDTA tubes using the standard PhenolChloroform method. Both the genotypes were determined by PCR-RFLP method according to previously published protocols (Agachan et al, 2005). PCR was carried out using gene specific oligonucleotide primers [Bioserve, India], respectively.

\section{PON1 ( L55M)}

Forward primer: 5' GAA GAG TGA TGT ATA GCC CCA 3'

Reverse primer: 5' TTT AAT CCA GAGCTA ATG AAA GCC 3' 
PON1 ( Q192R )

Forward primer: 5' TAT TGT TGC TGT GGG ACC TGA G 3'

Reverse primer: 5' CAC GCT AAA CCC AAA TAC ATC TC 3

Both the reactions were carried out in the presence of $1.5 \mathrm{mM} \mathrm{MgCl} 2,0.2 \mathrm{mM}$ dNTPs, and 1.2 units of Taq DNA polymerase and the steps included denaturation at $94^{\circ} \mathrm{C}$ for $5 \mathrm{~min}, 35$ cycles of $94^{\circ} \mathrm{C}$ for $30 \mathrm{~s}, 56^{\circ} \mathrm{C}$ for $45 \mathrm{~s}, 72^{\circ} \mathrm{C}$ for $45 \mathrm{~s}$ and a final extension step of $10 \mathrm{~min}$ at $72^{\circ} \mathrm{C}$. Genotyping was conducted in both exposed and control groups. PCR product of PON1 L55M polymorphism was incubated with NlaIII restriction enzyme for 3 hours to distinguish the polymorphic site. NlaIII restriction site occurs only in polymorphic allele. Wild type allele showed a single band at $170 \mathrm{bp}$ where as variant allele resulted in two fragments $126 \mathrm{bp} \& 44 \mathrm{bp}$. PCR Product of PON1 Q192R polymorphism was incubated with $A l w I$ restriction enzyme for 3 hours to distinguish the polymorphic site. AlwI restriction site occurs only in polymorphic allele. Wild type allele showed a single band at 99 bp where as variant allele resulted in two fragments $66 \mathrm{bp} \& 33 \mathrm{bp}$. Digested fragments were visualized by agarose gel electrophoresis (3\%) with ethidium bromide staining.

\section{Measurement of serum Paraoxonase enzyme:-}

Serum Paraoxonase enzyme levels were assessed using enzyme-linked immunosorbent assay (ELISA) kit (Wuhan EIAab Science Co., Ltd, Catalog \# EIA-E0243H, China) based on the sandwich principle and the detection range of the samples was $1.56-100 \mathrm{ng} / \mathrm{mL}$. The absorbance of the samples was measured by using a microplate reader at 450nm. PON1 in the samples was then determined by comparing the O.D. of the samples to the standard curve using Master Plex software.

\section{Statistical analysis:-}

The data is presented as the mean $\pm \mathrm{SD}$ and $p$ values were calculated using students' paired t-test. A comparison of variables between two groups was performed using the one-way ANOVA. Hardy-Weinberg equilibrium was tested for the gene polymorphisms and the association between genotypes was examined by odds ratio and chi-square analysis with threshold confidence interval (CI) of 95\% using open EPI6 software (Open Epi Version 2.3.1, Department of Epidemiology, Rollins School of Public Health, Emory University, Atlanta, GA 30322, USA). Haploview v4.0 (http://www.broad.mit.edu/mpg/haploview/) was used to determine the linkage disequilibrium in the PON1 region. A 2-tailed p-value of $<0.05$ was considered to be significant.

\section{Results:-}

The data on age, body mass index, working hours per day and duration of service are presented in table I. The serum paraoxonase enzyme levels were significantly low in exposed subjects when compared to control subjects. The mean serum levels were $7.61 \pm 2.11 \mathrm{ng} / \mathrm{ml}$ in the exposed women as against $13.09 \pm 3.80 \mathrm{ng} / \mathrm{ml}$ in control group and presented in table II.

\section{Table I. General characteristics of the study subjects.}

\begin{tabular}{|l|l|l|}
\hline Characteristics & Exposed $(\mathrm{n}=205)$ & Controls $(\mathrm{n}=212)$ \\
\hline Age $($ years $)$ & $35.65 \pm 7.91$ & $37.55 \pm 7.39$ \\
\hline Height $(\mathrm{ft})$ & $5.15 \pm 0.41$ & $5.34 \pm 0.24$ \\
\hline Weight $(\mathrm{kg})$ & $57.25 \pm 12.24$ & $52.92 \pm 5.56$ \\
\hline BMI $(\mathrm{kg} / \mathrm{m} 2)$ & $24.13 \pm 5.06$ & $20.44 \pm 2.78$ \\
\hline Working hours per day & $8.32 \pm 1.16$ & $8.18 \pm 1.45$ \\
\hline Duration of service (years) & $12.65 \pm 6.52$ & $12.81 \pm 5.46$ \\
\hline
\end{tabular}

Values are mean \pm standard deviation.

Table II:- Serum Paraoxonase levels in exposed and control groups.

\begin{tabular}{|l|l|}
\hline Group & Serum Paraoxonase enzyme $(\mathrm{ng} / \mathrm{mL})$ \\
\hline Exposed group $(\mathrm{n}=205)$ & $7.61 \pm 2.11^{*}$ \\
\hline Control group $(\mathrm{n}=212)$ & $13.09 \pm 3.80$ \\
\hline
\end{tabular}

$p$ values were calculated using Students' paired t-test.

$* p<0.05$ significant 
The genetic polymorphisms of PON1 gene were analyzed in both OP pesticide exposed women and controls by PCR-RFLP methods, respectively. The relationship between these genotypes and risk of disease susceptibility was assessed by means of odds ratio (OR) with 95\% confidence limits. The genotype distribution of PON1 L55M polymorphism in the exposed and controls are shown in Table III. The frequencies of the LL, LM and MM genotypes were found as 58,29,13\% in exposed and 67, 28, $5 \%$ in control subjects, respectively. Our results showed that the frequency of the mutant allele 'A' in PON1 L55M genotype was found to be $27 \%$ in exposed and $19 \%$ in controls $(\mathrm{OR}=1.64,95 \% \mathrm{CI}: 1.18-2.27 ; p<0.003)$.

Table III:- Genotype and allelic distribution of the PON1 L55M gene polymorphism in exposed and controls.

\begin{tabular}{|c|c|c|c|c|c|c|c|c|}
\hline \multirow[t]{2}{*}{ Inheritance model } & \multirow[t]{2}{*}{ Genotype } & \multicolumn{2}{|c|}{$\begin{array}{l}\text { Controls } \\
(\mathrm{N}=212)\end{array}$} & \multicolumn{2}{|c|}{$\begin{array}{l}\text { Exposed } \\
(\mathrm{N}=205)\end{array}$} & \multirow[t]{2}{*}{$\begin{array}{l}\text { Odds ratio } \\
(95 \%, \mathrm{CI})\end{array}$} & \multirow[t]{2}{*}{$\chi^{2}$} & \multirow[t]{2}{*}{$p$-Value } \\
\hline & & $\mathbf{n}$ & $\%$ & $\mathbf{n}$ & $\%$ & & & \\
\hline \multirow[t]{3}{*}{ Codominant } & TT & 143 & 67 & 119 & 58 & ref & & \\
\hline & TA & 59 & 28 & 60 & 29 & $1.22(0.79-1.88)$ & 0.63 & 0.42 \\
\hline & AA & 10 & 5 & 26 & 13 & $3.12(1.44-6.73)$ & 8.06 & $0.004^{*}$ \\
\hline \multirow[t]{2}{*}{ Dominant } & TT & 143 & 67 & 119 & 58 & ref & & \\
\hline & $\mathrm{TA}+\mathrm{AA}$ & 69 & 33 & 86 & 42 & $1.49(1.05-2.23)$ & 3.55 & 0.06 \\
\hline \multirow[t]{2}{*}{ Recessive } & AA & 10 & 5 & 26 & 13 & ref & & \\
\hline & $\mathrm{TA}+\mathrm{TT}$ & 202 & 95 & 179 & 87 & $2.93(1.37-6.25)$ & 7.40 & $0.006^{*}$ \\
\hline \multirow[t]{3}{*}{ Allele Frequencies } & Alleles & & & & & & & \\
\hline & $\mathrm{T}$ & 345 & 81 & 298 & 73 & ref & & \\
\hline & A & 79 & 19 & 112 & 27 & $1.64(1.18-2.27)$ & 8.41 & $0.003^{*}$ \\
\hline
\end{tabular}

$* p<0.05$ significant

Ref-reference

The genotype distribution of the PON1 Q192R polymorphism in the exposed and controls are shown in Table IV. The frequencies of the QQ, QR and RR genotypes were found as 45, 50, $5 \%$ in exposed and 51, 40, $9 \%$ in control subjects, respectively. The frequency of the mutant allele ' $G$ ' in PON1 Q192R genotype was slightly higher in the exposed group (30\%) than in the control group (29\%) and this difference was not statistically significant $(\mathrm{OR}=$ 1.06, 95\% CI: $0.78-1.42 ; p=0.7$ ).

Table IV:- Genotype and allelic distribution of the PON1 Q192R gene polymorphism in exposed and controls.

\begin{tabular}{|c|c|c|c|c|c|c|c|c|}
\hline \multirow[t]{2}{*}{ Inheritance model } & \multirow[t]{2}{*}{ Genotype } & \multicolumn{2}{|c|}{$\begin{array}{l}\text { Controls } \\
(\mathrm{N}=212)\end{array}$} & \multicolumn{2}{|c|}{$\begin{array}{l}\text { Exposed } \\
(\mathrm{N}=205)\end{array}$} & \multirow[t]{2}{*}{$\begin{array}{l}\text { Odds ratio } \\
(95 \%, C I)\end{array}$} & \multirow[t]{2}{*}{$\chi^{2}$} & \multirow[t]{2}{*}{$p$-Value } \\
\hline & & $\mathbf{n}$ & $\%$ & n & $\%$ & & & \\
\hline \multirow[t]{3}{*}{ Codominant } & AA & 108 & 51 & 92 & 45 & ref & & \\
\hline & AG & 85 & 40 & 102 & 50 & $1.40(0.94-2.10)$ & 2.49 & 0.11 \\
\hline & GG & 19 & 9 & 11 & 5 & $0.67(0.31-1.50)$ & 0.58 & 0.44 \\
\hline \multirow[t]{2}{*}{ Dominant } & $\mathrm{AA}$ & 108 & 51 & 92 & 45 & ref & & \\
\hline & $\mathrm{AG}+\mathrm{GG}$ & 104 & 49 & 113 & 55 & $1.27(0.86-1.8)$ & 1.30 & 0.25 \\
\hline \multirow[t]{2}{*}{ Recessive } & GG & 19 & 9 & 11 & 5 & ref & & \\
\hline & $\mathrm{AG}+\mathrm{AA}$ & 193 & 91 & 194 & 95 & $0.57(0.26-1.24)$ & 1.51 & 0.21 \\
\hline \multirow[t]{3}{*}{ Allele Frequencies } & \multicolumn{2}{|l|}{ Alleles } & & & & & & \\
\hline & A & 301 & 71 & 286 & 70 & ref & & \\
\hline & $\mathrm{G}$ & 123 & 29 & 124 & 30 & $1.06(0.78-1.42)$ & 0.09 & 0.7 \\
\hline
\end{tabular}

$* p<0.05$ significant

Ref-reference

When we compared the serum PON1 enzyme levels of 3 genotypes for control and exposed subjects we found significantly lower serum PON1 enzyme levels in the exposed group when compared to control subjects in all three genotypes of both the polymorphisms. The association of PON1 L55M genotypes and serum PON1 levels of the exposed and control group were shown in Table V. Low serum PON1 enzyme levels were found in AA recessive genotype of both control $(7.12 \mathrm{ng} / \mathrm{ml})$ and exposed group $(5.19 \mathrm{ng} / \mathrm{ml})$. The relationship between PON1 Q192R genotypes and serum PON1 levels of the exposed and control group were shown in Table V. In AA genotype serum PON1enzyme levels were low in exposed $(6.58 \mathrm{ng} / \mathrm{ml})$ and control groups $(11.09 \mathrm{ng} / \mathrm{ml})$ when compared to AG and GG genotypes. Serum PON1 enzyme levels differences between genotypes of PON1 L55M and PON1 Q192R 
polymorphisms were analyzed by ANOVA. The results revealed significant enzyme level differences between the three genotypes of both the polymorphisms $(\mathrm{p}<0.01)$.

Table V:- Association of serum paraoxonase levels in relation to PON1 L55M \& PON1 Q192R gene polymorphism.

\begin{tabular}{|l|l|l|l|l|l|l|}
\hline Gene & $\mathrm{n}$ & Control & $\mathrm{n}$ & Exposed & $p$ Value \\
\hline \multirow{2}{*}{$\begin{array}{l}\text { PON1 } \\
\text { L5M }\end{array}$} & TT & 143 & $14.44 \pm 0.31$ & 119 & $8.65 \pm 0.15$ & $0.001^{*}$ \\
\cline { 2 - 7 } & TA & 59 & $12.45 \pm 0.42$ & 60 & $6.57 \pm 0.21$ & $0.001^{*}$ \\
\cline { 2 - 7 } & AA & 10 & $7.12 \pm 0.43$ & 26 & $5.19 \pm 0.36$ & $0.001^{*}$ \\
\hline \multicolumn{2}{|l|}{ ANOVA $p$ Value } & & $0.003^{*}$ & & $0.001^{*}$ & \\
\hline \multirow{2}{*}{$\begin{array}{l}\text { PON1 } \\
\text { Q192R }\end{array}$} & AA & 108 & $11.09 \pm 0.87$ & 92 & $6.58 \pm 0.57$ & $0.0001^{*}$ \\
\cline { 2 - 7 } & AG & 85 & $12.31 \pm 0.36$ & 102 & $8.07 \pm 0.15$ & $0.0001^{*}$ \\
\cline { 2 - 7 } & GG & 19 & $13.98 \pm 0.38$ & 11 & $11.83 \pm 0.19$ & $0.003^{*}$ \\
\hline
\end{tabular}

Paraoxonase levels are given as $\mathrm{ng} / \mathrm{mL}$ (Mean $\pm \mathrm{SE}$ )

$p$ values were calculated using Students' paired t-test. $* p<0.05$ significant

Analysis of variance was used to test for differences between the groups.

Linkage disequilibrium analysis (LD) defined by the delta coefficient $\left(\mathrm{D}^{\prime}\right)$, was determined for both exposed and control groups for two SNPs, PON1 L55M and PON1 Q192R. Strong linkage disequilibrium was observed between the two polymorphisms with $\mathrm{D}^{\prime}-0.744$ and LOD score value of 40.33 (Fig. 1).

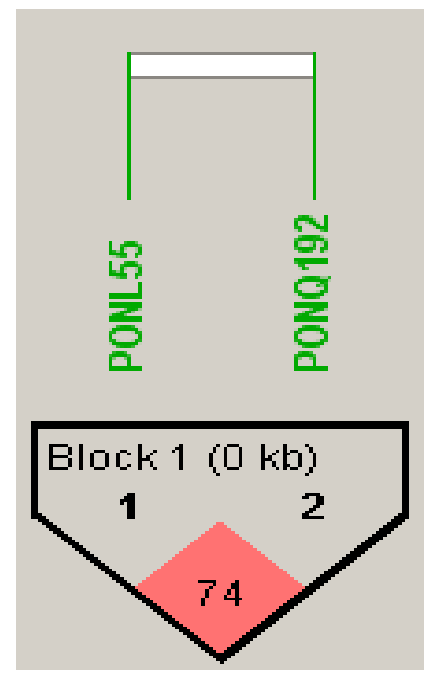

Figure 1:- Linkage disequilibrium pattern of PON1 genetic variants PON1 L55M (T>A) and PON1 Q192R (A>G) in the OP exposed and control subjects in South Indian population. The single nucleotide polymorphisms (SNPs) in Chromosome 7 were positioned according to the order and orientation. Pink color represent a very strong LD pattern $\left(\mathrm{D}^{\prime}>0.7\right)$

\section{Discussion:-}

Several studies demonstrated the importance of PON1 polymorphisms in the efficacy of OP detoxification and relevancy for human health risk assessment but only few investigations aimed to identify susceptible populations among groups that are occupationally exposed to OPs. Our study is one among them mainly aimed to assess paraoxonase and its risk with long term exposure to OP pesticides.

Paraoxonases are the enzymes responsible for the metabolism organophosphate compounds. It is hypothesized that individuals with low serum activity of this enzyme would be expected to have low ability to metabolize organophosphate compounds ( Geldmacher-von Mallinckrodt and Diepgen, 1988). Earlier studies on animals have also demonstrated the role of PON1 in decreasing the toxicity of organophosphate pesticides. Rats injected with PON1 showed increased resistance towards OPs than in controls (Costa et al., 2005a; Li et al., 1995). In PON1 
knockout mice experiment with absence of PON1 plasma activity, the sensitivity to OPs mediated toxicity was found to be increased (Furlong et al., 2005; Li et al., 1993; Li et al., 2000). PON1 knockout mice expressing human PON1R192 were significantly less sensitive to the toxicity of OPs than PON1Q192 or PON1 knockout mice (wild type) (Costa et al., 2005a). The individual genetic variability in metabolizing enzymes are involved in genotoxic risk of humans. The inefficiency of humans towards detoxification may lead to the metabolic sub-products accumulation contributing to a possible tumorigenic progression (Hodgson et al., 1991). Several enzymatic isoforms have been observed to contribute to individual cancer susceptibility as genetic modifiers of cancer risk after exposure to genotoxic agents (Bolognesi, 2003).

PON1 in humans exhibits genetic polymorphisms in coding and promoter regions, leading to the change in serum PON1 levels (Davies et al., 1996; Suheiro et al., 2000; Brophy et al., 2001). In the present investigation a wide variation in PON1 serum levels between exposed and control groups were observed. In PON1 Q192R polymorphism PON1 serum levels was observed low in Q/Q and Q/R genotypes and highest was observed in R/R genotype within both study groups. These results are in consistent with previous findings that the phenotypes showing low activity contain Q allele (Humbert et al., 1993; Li et al., 2000; Sirivarasai et al., 2007; Chia et al., 2009; Lopez-Flores et al., 2009).

In the present study, the wild type PON1 L55M polymorphism showed higher serum PON1 levels followed by hetero-genotype and significantly low serum levels were observed in recessive genotype of both the groups which is in agreement with the earlier studies indicating L allele genotype of PON1 L55M polymorphism is associated with higher serum PON1 levels by producing more PON1 mRNA (Leviev and James, 2000; Furlong et al., 2006; Sirivarasai et al., 2007). Therefore, in PON1 polymorphisms serum from $\mathrm{L} / \mathrm{L}$ and $\mathrm{R} / \mathrm{R}$ individuals had significantly higher PON1 enzyme concentration than serum from other genotype individuals (Garin et al.,1997). Thus, serum paraoxonase concentration and activity with reference to polymorphisms was found to be in the following order: PON1192 R/R > Q/R > Q/Q and PON1 55 L/L > L/M > M/M, which has also been reported previously in different population ( Rojas-Garcia et al., 2005; Catano et al., 2006; Lopez-Flores et al.,2009). Thus, the results of the present investigation suggest that the PON1 genotype and serum levels might have an important role in the identification of individuals with higher risk of health hazards due to OPs occupational exposure.

Landers et al (2008) observed the PON cluster in linkage disequilibrium and reported that significant association of PON1 L55M and PON1 Q192R gene polymorphisms may lead to disease susceptibility. In the present study genotyping results were used to determine the linkage disequilibrium between the 2 SNPs within the PON1 gene cluster as shown in Figure 1. The current study confirms the previous reports that genetic variants within the PON1 gene are in strong linkage disequilibrium and are associated with OP exposure risk leading to disease susceptibility.

\section{Conclusion:-}

Despite of limited statistical power the present study has several important implications for human paraoxonase 1 and its risk with occupational OP exposed. In our study exposed group showed lower levels of serum PON1 enzyme, suggesting that study population might be less protected or more sensitive to OP exposure. From the present study we also suggest that serum paraoxonase levels are affected by PON1 genetic variability in exposed and controls. Thus the study emphasizes the importance of serum PON1 enzyme levels and its association with PON1 gene polymorphisms and it can be considered as a potential biomarker for OP-susceptible individuals, especially in occupationally exposed populations. It is henceforth suggested that further more occupational studies are needed in this field to support our observations.

\section{Abbreviations used:-}

Paraoxonase (PON), Organophosphates (Ops), Enzyme-Linked Immunosorbent Assay (ELISA), Odds Ratio (OR), Class Interval (CI), Linkage Disequilibrium Analysis (LD) Analysis of variance (ANOVA).

\section{Acknowledgements:-}

* The authors are thankful to all the study subjects who volunteered to make this investigation successful.

* There is no conflict of interest.

\section{Funding:-}

This study was funded by the Department of Biotechnology, Government of India. 


\section{References:-}

1. Agachan B, Yilmaz H.,. Ergen H. A,. Karaali Z. E, Isbir T.. , 2005 Paraoxonase (PON1) 55 and 192 Polymorphism and Its Effects to Oxidant-Antioxidant System in Turkish Patients with Type 2 Diabetes Mellitus. Physiol. Res. 54: 287-293.

2. Aristidis M. Tsatsakis, Vasilis P. Androutsopoulos, Alexandros Zafiropoulos, Fotoula Babatsikou,Thanasis Alegakis, Ioanna Dialyna, Manolis Tzatzarakis, and Charilaos Koutis. 2011.Associations of xenobioticmetabolizing enzyme genotypes PON1Q192R, PON1L55M and CYP1A1*2A MspI with pathological symptoms of a rural population in south Greece. Xenobiotica. 2011 Oct;41(10):914-25.

3. Baldi, I., Robert, C., Piantoni, F., Tual, S., Bouvier, G., Lebailly, P., and Raherison, C. 2014. Agricultural exposure and asthma risk in the AGRICAN French cohort.Int. J. Hyg.Environ. Health 217: 435-442.

4. Bolognesi, C., 2003. Genotoxicity of pesticides: a review of human biomonitoring studies. Mutat. Res. 543, 251-272.

5. Brophy, V.H., Jampsa, R.L., Clendenning, J.B., McKinstry, L.A., Jarvik, G.P., Furlong, C.E., 2001. Effects of $5^{\prime}$ regulatory-region polymorphisms on paraoxonase-gene (PON1) expression. Am. J. Hum. Genet. 68, 1428 1436.

6. Catano, H.C., Carranza, E., Huamani, C., Hernandez, A.F., 2008. Plasma cholinesterase levels and health symptoms in Peruvian farm workers exposed to organophosphate pesticides. Arch. Environ. Contam. Toxicol. 55 (1), 153-159.

7. Chia, S.E., Mohamed, A.S., Yap, P.H., Gan, L., Ong, Y.B., Chia, K.S., 2009. Distribution of PON1 polymorphisms PON1Q192R and PON1L55M among Chinese, Malay and Indian males in Singapore and possible susceptibility to organophosphate exposure. Neurotoxicology 30, 214-219.

8. Costa LG, Li WF, Richter RJ, Shih DM, Lusis A, Furlong CE. 1999.The role of paraoxonase (PON1) in the detoxication of organophosphates and its human polymorphism.Chem Biol Interact. 1999 May 14; 119120:429-38.

9. Costa LG, Li W-F, Richter RJ, Shih DM, Lusis AJ, Furlong CE. 1999. The role of paraoxonase (PON1) in the detoxication of organophosphates and its human polymorphism. Chem Biol Interact. :119-120. 429-38.

10. Costa LG, Vitalone A, Cole TB, Furlong CE. 2005a Modulation of paraoxonase (PON1) activity. BiochemPharmacol; 69: 541-50.

11. Costa LG. 2006.Current issues in organophosphate toxicology. Clin Chim Acta. Apr; 366(1-2):1-13.

12. Costa, L.G.; Cole, T.B.; Vitalone, A. \& Furlong, C.E. 2005b. Measurement of Paraoxonase Status as a Potential Biomarker of Susceptibility to Organophosphate Toxicity. Clinica Chimica Acta, Vol. 352, pp. 37-47.

13. Davies, H., Richter, R.J., Kiefer, M., Broom field, C., Sowalla, J., Furlong, C.E., 1996. The effect of the human serum paraoxonase polymorphism is reversed with diazoxon, soman and sarin. Nat. Genet. 14, $334-336$.

14. Furlong, C.E., Holland, N., Richter, R.J., Bradman, A., Ho, A., Eskenazi, B., 2006. PON1 status of farmworker mothers and children as a predictor of organophosphate sensitivity. Pharmacogenet. Genomics 16, 183-190.

15. Garin, M.C., James, R.W., Dussoix, P., et al., 1997. Paraoxonase polymorphism Met-Leu54 is associated with modified serum concentrations of the enzyme: a possible link between the paraoxonase gene and increased risk of cardiovascular disease in diabetes. J. Clin. Invest. 99, 62-66.

16. Geldmacher-von Mallinckrodt, M., Diepgen, T.L., 1988. The human serum paraoxonase polymorphism and specificity. Toxicol. Environ. Chem. 18, $179-196$

17. Hernandez, A.F.; Mackness, B.: Rodrigo, L.; Lopez, O.; Pla, A.; Gil, F.; Durrington, P.N.; Pena, G.; Parron, T.; Serrano, J.L.; \& Mackness, M.I. 2003. Paraoxonase Activity and Genetic Polymorphisms in Greenhouse Workers with Long Term Pesticide Exposure. Human and Experimental Toxicology, Vol.22, pp. 565-574.

18. Hodgson, E., Silver, I.S., Butler, L.E., Lawton, M.P., Levi, P.E., 1991. Metabolism. In: Hayes, W.J., Laws, E.R. (Eds.), Handbook of Pesticides Toxicology, Vol. 1. Academic Press, San Diego, CA, pp. 106-167.

19. Humbert, R., Adler, D.A., Disteche, C.M., Hassett, C., Omiecinski, C.J., Furlong, C.E., 1993. The molecular basis of the human serum paraoxonase activity polymorphism. Nat. Genet. 3, 73-76.

20. Landers JE1, Shi L, Cho TJ, Glass JD, Shaw CE, Leigh PN, Diekstra F, Polak M, Rodriguez-Leyva I, Niemann S, Traynor BJ, McKenna-Yasek D, Sapp PC,Al-Chalabi A, Wills AM, Brown RH Jr. 2008. A common haplotype within the PON1 promoter region is associated with sporadic ALS. Amyotroph Lateral Scler. 2008 Oct;9(5):306-14.

21. Leviev, I., James, R.W., 2000. Promoter polymorphisms of human paraoxonase PON1 gene and serum paraoxonase activities and concentrations. Arterioscler. Thromb. Vasc. Biol. 20, 516 - 521.

22. Li, W. F., Costa, L. G., and Furlong, C. E. 1993. Serum paraoxonase status-A major factor in determining resistance to organophosphates. J. Toxicol. Environ. Health 40: 337-346. 
23. Li, W. F., Costa, L. G., Richter, R. J., Hagen, T., Shih, D. M., Tward, A., Lusis, A. J., and Furlong, C. E. 2000. Catalytic efficiency determines the in-vivo efficacy of PON1 for detoxifying organophosphorus compounds. Pharmacogenetics 10: 767-779.

24. Lopez-Flores, I., Lacasana, M., Blanco-Munoz, J., Aguilar-Garduno, C., Sanchez-Villegas, P., Perez-Mendez, O.A., Gamboa-Avila, R., 2009. Relationship between human paraoxonase-1 activity and PON1 polymorphisms in Mexican workers exposed to organophosphate pesticides. Toxicol. Lett. 188, 84-90.

25. Mackenzie Ross, S. J., Brewin, C. R., Curran, H. V., Furlong, C. E., Abraham-Smith, K. M., and Harrison, V. 2010. Neuropsychological and psychiatric functioning in sheep farmers exposed to low levels of organophosphate pesticides. Neurotoxicol. Teratol. 32:452-459.

26. Perez-Herrera, N.; Polanco-Minaya; H., Salazar-Arredondo; E., Solis-Heredia M.J.; Hernandez-Ochoa I.; Rojas-Garcia E.; Alvarado-Mejia J.; Borja-Aburto, V.H. \& Quintanilla-Vega, B. 2008. PON1Q192R Genetic Polymorphism Modifies Organophosphorous Pesticide Effects on Semen Quality and DNA Integrity in Agricultural Workers from Southern Mexico. Toxicology and Applied Pharmacology, Vol. 230, pp. $261-268$.

27. Rojas-Garcia, A.E., Solis-Heredia, M.J., Pina-Guzman, B., Vega, L., Lopez-Carrillo, L., Quintanilla-Vega, B., 2005. Genetic polymorphisms and activity of PON1 in a Mexican population. Toxicol. Appl. Pharmacol. 205, $282-289$.

28. Sirivarasai J, Kaojarern S, Yoovathaworn K, Sura T. 2007. Paraoxonase (PON1) polymorphism and activity as the determinants of sensitivity to organophosphates in human subjects. Chemico-Biological Interactions, Vol. 168, pp. 184-192.

29. Suheiro, T., Nakamura, T., Inoue, M., Shiinoki, T., Ikeda, Y., Kumon, Y., Shindo, M., Tanaka, H., Hashimoto, K., 2000. A polymorphism upstream from the human paraoxonase (PON1) gene and its association with PON1 expression. Atherosclerosis 150,295- 298.

30. Tsatsakis AM, Zafiropoulos A, Tzatzarakis MN, Tzanakakis GN, Kafatos A. 2009. Relation of PON1 and CYP1A1 genetic polymorphisms to clinical findings in a cross-sectional study of a Greek rural population professionally exposed to pesticides. Toxicol Lett 186:66-72.

31. Vakonaki, E., Androutsopoulos, V. P., Liesivuori, J., Tsatsakis, A. M., and Spandidos, D. A. 2013. Pesticides and oncogenic modulation. Toxicology 307: 42-45.

32. Zhou, Z.J.; Zheng, J.; Wu, Q.E. \& Xie, F. 2007. Carboxylic Esterase and its Associations With Long-term Effects of Organophosphorus Pesticides. Biomedical Environmental Sciences, Vol. 20, pp. 284-290. 